\title{
$\angle$ Research Square \\ Oxidative Stress Induced By The Metallic Oxide The Copper Oxide (Cuo-Nps) On Terrestrial Snail Helix Aspersa
}

\section{Benamara Maroua}

Chadli Benjdid El Tarf University

\section{Amrani Amina}

Chadli Benjdid El Tarf University

\section{Zaidi Hadjer}

Chadli Benjdid El Tarf University

\section{Sedrati Fateh}

Chadli Benjdid El Tarf University

\section{Bouroumana Selma}

Chadli Benjdid El Tarf University

\section{Zouzou Dalel}

Chadli Benjdid El Tarf University

\section{Kerkoub Naila}

Chadli Benjdid El Tarf University

\section{Bouarroudj Tayeb}

Centre de Recherche Scientifique et Technique en Analyses Physico - Chimiques (CRAPC)

Nasri Hichem ( $\boldsymbol{\sim}$ h.nasri@atrss.dz)

Chadli Benjdid El Tarf University https://orcid.org/0000-0001-6343-1412

\section{Research Article}

Keywords: Copper Oxide Nanoparticles, CuO-NPs, Helix aspersa, hepatotoxicity, oxidative stress biomarkers.

Posted Date: December 9th, 2021

DOI: https://doi.org/10.21203/rs.3.rs-1132432/v1

License: (c) (1) This work is licensed under a Creative Commons Attribution 4.0 International License.

Read Full License 


\section{Abstract}

Our study focused on the evaluation of the toxicity of copper oxide nanoparticles (CuO-NPs) on a bioindicator; the land snail Helix aspersa. Their effects were studied by a targeted approach in the laboratory, by evaluating the oxidative stress biomarkers in hepatopancreas and kidney (GSH, GST, GPX, CAT, and LPO). The snails were exposed to increasing concentrations $(50,100,150$, and $200 \mathrm{mg} / \mathrm{kg}$ ) of CuO-NPs mixed in wheat flour during a sub-chronic treatment period of 45 days. Our results show that: CuO-NPs can induce oxidative stress, by producing reactive oxygen species (ROS), which was confirmed by the decrease in glutathione (GSH) level and reduction of its metabolizing enzyme glutathione-stransferase (GST) in both organs, as they trigger the detoxification system resulting in increased activity of the glutathione peroxidase (GPx) and catalase defense enzyme and lipide peroxidation indices within the hepatopancreas.

\section{Highlights}

- Exposure of Helix aspersa to copper oxide (CuO) induced hepatotoxicity and nephrotoxicity.

- CuO activated the detoxification system in hepatopancreas.

- The Higher level of lipid peroxidation was detected in kidney.

\section{Introduction}

Currently, nanotechnologies and nanoscience are booming and represent a key development in the innovative materials sectors, new productions containing nanomaterials are constantly marketed (François, 2012).

Due to their nanometric size, nanomaterials have different advantageous physicochemical properties, which have already found various applications; cosmetics (sunscreen), textiles, ceramics, chemical and pharmaceutical industries (drug administration), and water treatment (Rossi, 2006).

This raised development of their uses has increased the concentrations of nanoparticles in air, water and soil, which could as a result reach ecosystems, and accentuate the risk of exposure to nanometric contaminants, all that makes the study and management of their toxicological risk difficult to establish considering that several aspects of their toxicity mechanisms are not yet well understood (Rossi, 2006; François, 2012).

To allow responsible and safe development of nanotechnologies using metallic NPs, a better understanding of their cytotoxicity mechanisms is therefore required (François, 2012). However, these unique properties make them very reactive and allow them to easily penetrate cells, resulting in possible nano toxicity to microorganisms, plants and animals (Ghosh et al. 2016). The toxicity of different types of nanoparticles is suspected to be behind the generation of reactive oxygen species (ROS). Oxidative stress is a response to cell damage, in vivo and in vitro studies have shown that nanoparticles generate 
more free radicals and reactive oxygen species than larger particles due to their large surface area. ROS are known for their ability to damage cells by oxidizing lipids, disrupting DNA and modifying proteins, among other interfaces. (Huang et al. 2017)

CuO-NPs has potentially wide industrial use in applications such as gas sensors, antimicrobial coatings, photovoltaic cells, in catalyst applications, and in heat transfer nanofluids. Changes in the

physicochemical and structural properties of nanomaterials due to the decrease in particle size can lead to biological effects that are difficult to predict from other forms of the same metal. Several Studies have demonstrated that CuO-NPs are up to 50 -fold more toxic than bulk $\mathrm{CuO}$ to crustaceans (Heinlaan et al. 2008), algae (Aruoja et al. 2009), protozoa (Mortimer et al. 2010), and yeast (Kasemets et al. 2009).

The aim of this study is to understanding the biological interactions between a bio indicator, known for its important bio-accumulating power in its tissues, the land snail (Helix aspersa), with nanoparticles CuONPs, through a battery of enzymatic and non-enzymatic biomarkers of oxidative stress.

\section{Materiel Et Methods}

\subsection{Biological material}

The terrestrial gastropod: Helix aspersa, was supplied from a snail farm in Bouchegouf (Guelma, NorthEast Algeria), with a medium weight of $8.5 \pm 0.15 \mathrm{~g}$. They were maintained under optimal environmental conditions: photoperiods $18 \mathrm{~h}$ of light $/ 24 \mathrm{~h}$, temperature $\left(20^{\circ} \mathrm{C} \pm 2^{\circ} \mathrm{C}\right)$, hygrometry from 80 to $95 \%$, food with wheat flour. (Coeurdassier et al. 2000).

\subsection{Chemical material}

CuO used in this study is a commercial preparation, from the Center for Scientific and Technical Research in Physico-Chemical Analysis (CRAPC)- Bou-Ismail- Tipaza, Algeria.

\subsubsection{Characterisation of CuO-NPs nanoparticles}

The X-ray diffraction (XRD) patterns were recorded on a Siemens D-5000 diffractometer with Cu-Ka radiation $(\lambda=1.5418 \AA$ ). The morphology of sample was studied using Transmission Electron Microscopy (TEM) images.

\subsubsection{Preparation of CuO-NPs nanoparticles}

In $40 \mathrm{~mL}$ of distilled water, $4 \mathrm{mmol}$ of $\mathrm{CuSO}_{4} \cdot 5 \mathrm{H}_{2} \mathrm{O}$ was dissolved, then $4 \mathrm{~mL}$ of cyclohexylamine was added dropwise under intense stirring, and the agitation was continuously sustained for 30 minutes. Finally, the mixture was moved to an autoclave of Teflon-lined stainless steel that was sealed and held for $16 \mathrm{~h}$ at $140 \mathrm{C}^{\circ}$. The autoclave was naturally cooled down to room temperature, and the sample was purified and washed several times with distilled water and ethanol, and vacuum-dried for $9 \mathrm{~h}$ at $80 \mathrm{C}^{\circ}$.

\subsection{Experimental design}


For 45 days, the snails were fed with 04 different concentrations of copper oxide $(50,100,150$, and 200 $\mathrm{mg} / \mathrm{kg})$ mixed in one and a half kilograms $(1.5 \mathrm{~kg})$ of wheat flour. The control group was fed with uncontaminated flour. After the treatment period, all individuals were left on an empty stomach for 48 hours to empty the contents of their digestive tract, sacrificed and dissected. The hepatopancreas and kidneys were removed and fixed for antioxidants determination.

\subsection{Oxidative stress biomarkers}

Frozen snail tissues aliquots were thawed in crushed ice and homogenized with $10 \mathrm{mM}$ ice-cold Tris- $\mathrm{HCl}$ buffer ( $\mathrm{pH}$ 7.4) using a manual homogenizer. The homogenate was then vortexed and centrifuged at $10,000 \mathrm{~g}$ for $10 \mathrm{~min}$ at $4^{\circ} \mathrm{C}$. Aliquots of each supernatant were used to measure total protein content and oxidative stress biomarkers by spectrophotometric methods. The protein content was measured by the Bradford dye-binding assay with bovine serum albumin as a standard (Bradford, 1973).

The GSH content was quantified using Elman's reagent (DTNB) as a fluorescent reagent reported by Weckberker and Cory (1988). Briefly, the reaction mixture contained $500 \mu \mathrm{L}$ of the supernatant of each tissue sample, $1.0 \mathrm{ml}$ Tris-EDTA buffer $(0.02 \mathrm{M}, \mathrm{pH} 9.6)$, and $25 \mu \mathrm{LTNB}(0.01 \mathrm{M})$. After thorough mixing and incubation at room temperature for $5 \mathrm{~min}$, the fluorescence at $412 \mathrm{~nm}$ was determined, and GSH concentration values were calculated from a pure GSH standard curve. The rate of GSH was expressed as nanomoles of glutathione formed per milligram of proteins (nmol GSH/mg protein).

GST activity was measured using 1-chloro-2,4-dinitrobenzene (CDNB) as a substrate as described by Habig et al. (1974). Briefly, the reaction mixture containing $50 \mu \mathrm{l}$ of each tissue supernatant, $1.05 \mathrm{ml}$ of $100 \mathrm{mM}$ Tris buffer (pH 7.4), $50 \mu \mathrm{l}$ of $1 \mathrm{mM} \mathrm{CDNB}$, and $50 \mu \mathrm{l}$ of $1 \mathrm{mM} \mathrm{GSH}$. The GST activity was determined by monitoring changes in absorbance at $340 \mathrm{~nm}$ for $2 \mathrm{~min}$, reflecting the rate of CDNB conjugation with GSH, and using an extinction coefficient of $9.6 \mathrm{mM}-1 \mathrm{~cm}-1$. One unit $(U)$ of glutathiones-transferase activity is defined as the amount of enzyme that conjugates $1 \mu$ mole of CDNB per min. The GST activity was expressed as $\mathrm{U} / \mathrm{mg}$ protein.

The enzymatic activity of glutathione peroxidase (GPx) was measured by the method of Flohé and Günzler (1984). This method is based on the reduction of hydrogen peroxide $\left(\mathrm{H}_{2} \mathrm{O}_{2}\right)$ in the presence of reduced glutathione (GSH), the latter is transformed into (GSSG) under the influence of GPx. the method consists to Incubate $0.2 \mathrm{ml}$ of the homogenate, $0.4 \mathrm{ml}$ of GSH $(0.1 \mathrm{mM})$ and $0.2 \mathrm{ml}$ of the TBS buffer solution (50 mM Tris, $150 \mathrm{mM} \mathrm{NaCl}, \mathrm{pH} 7.4$ ) in a water bath at $25^{\circ} \mathrm{C}$ for $5 \mathrm{~min}$. then, add $0.2 \mathrm{ml} \mathrm{of} \mathrm{H}_{2} \mathrm{O}_{2}$ $(1.3 \mathrm{mM})$ to initiate the reaction, after 10 minutes we add $1 \mathrm{ml}$ of TCA $(1 \%)$ to stop the reaction. the mixture is put in ice for 30 minutes, centrifuged for 10 minutes at $3000 \mathrm{rpm}$. The final mixture contains $0.48 \mathrm{ml}$ of the supernatant, $2.2 \mathrm{ml}$ of the TBS buffer solution, and $0.32 \mathrm{ml}$ DTNB (1 mM). the optical densities were read at $412 \mathrm{~nm}$ against the blank.

CAT activity was measured at $240 \mathrm{~nm}$ by determining the decrease in the level of hydrogen peroxide (Beers and Sizer, 1952). The reaction mixture contains $1.9 \mathrm{ml}$ of $50 \mathrm{mM}$ phosphate buffer (pH 7.0), $1.0 \mathrm{ml}$ of $5 \mathrm{mM} \mathrm{H}_{2} \mathrm{O}_{2}$, and $100 \mu \mathrm{L}$ of tissue supernatant. A unit of CAT activity is defined as the quantity of 
enzyme catalyzing the degradation of $1 \mu \mathrm{mol}$ of $\mathrm{H} 2 \mathrm{O} 2$ per minute and the specific activity corresponding to the transformation into $\mu$ moles of the substrate $\left(\mathrm{H}_{2} \mathrm{O}_{2}\right)$ per minute per mg of protein.

Lipid peroxidation (LPO) levels were assayed by measurement of malondialdehyde (MDA). The decomposition product of polyunsaturated fatty acids hydroperoxides was determined by the thiobarbituric acid (TBA) reaction as described by Fatima et al. (2000) with some modifications by Zhao et al. (2009). Briefly, the assay mixture contained $1 \mathrm{~mL}$ tissue supernatant, $1 \mathrm{ml}$ of $5 \%$ trichloroacetic acid (TCA), and $1 \mathrm{ml}$ of $0.67 \%$ thiobarbituric acid (TBA). The mixture was heated at $95^{\circ} \mathrm{C}$ for $40 \mathrm{~min}$, cooled, and centrifuged at $3000 \mathrm{~g}$ for $10 \mathrm{~min}$. The absorbance of the supernatant was determined at $532 \mathrm{~nm}$. The amount of thiobarbituric acid reactive substances (TBARS) was calculated using an extinction coefficient of $1.56 \times 105 \mathrm{M}-1 \mathrm{~cm}-1$. The rate of lipid peroxidation was expressed as nanomoles of substances reactive to thiobarbituric acid (TBARS) formed per hour, per milligram of proteins (nmol. TBARS/mg protein).

\subsection{Statistical analysis}

The data from CuO-NPs administration and control snails were presented as mean \pm S.E $(n=25$, five different animals, and each analysis from each one was repeated three different times in hepatopancreas and kidney). Groups means were compared using one-way ANOVA, when ANOVA was significant multiple comparisons of mean values were separated by Tukey's test. Statistical differences were determined at the $\mathrm{P}<0.05$ and $\mathrm{P}<0.01$ level for all analyses.

\section{Results}

\subsection{Copper oxide characterization}

The Powder X-ray diffraction (XRD) pattern of CuO-NPs nanoparticles as shown in Figure 1-A.

The diffraction peaks of this product are ascribed to the formation of the CuO-NPs (space group C2/c) monoclinic crystal phase with constants of $a=4.69 \AA, b=3.42 \AA, c=5.13 \AA$, (JCPDS 41- 0254). In the XRD spectrum of our sample, no peaks from impurities can be detected, showing the high purity of CuONPs products and also, the sharp and extreme peaks in the XRD patterns of the products suggest strong CuO-NPs crystallinity.

The average particle size of the samples was calculated using the following Scherrer equation: $D=9 \lambda / \beta$ $\cos \theta$, where $\beta$ exceeds the diffraction peak distance line in radians, $\theta$ is the angle of Bragg in degrees, $d$ is the crystal average diameter and $\lambda$ is the $X$-ray wavelength in angstrom (Nezamzadeh-Ejhieh and Amiri, 2013). The average crystallite size of the nanoparticles of CuO-NPs is estimated about $29 \mathrm{~nm}$ by Scherer's formula.

The TEM image (Figure 1-B) demonstrates that the substance consists of normal morphology and narrow size distribution of spherical particles. The size of the particles shown in the TEM picture is in Strong accordance with that calculated by the XRD pattern of the Debye-Scherrer formula. 


\subsection{Biochemical results}

A non-significant variation ( $p>0.05$ ), of the glutathione level, was detected at the level of the two organs in question; hepatopancreas and kidney; of Helix aspersa exposed to a commercial preparation of copper oxide.

In hepatopancreas, the highest value was noted in the control group; $5.13 \pm 1.81 \mathrm{nmol} / \mathrm{mg}$ protein. This value was reduced in snails exposed to $50 \mathrm{mg} / \mathrm{kg}$ of CuO-NPs; to $3.03 \pm 0.99 \mathrm{nmol} / \mathrm{mg}$ of protein. A similarity of effects was noted for the rest of the doses (Figure 2-A, Table 1).

Stability of renal glutathione was observed following treatment with CuO-NPs (Figure 2-A, Table 2), except for the case of $150 \mathrm{mg} / \mathrm{kg}$, a non-significant reduction was reported with $1.90 \pm 0.03 \mathrm{nmol} / \mathrm{mg}$ of protein compared to the control $3.49 \pm 1.46 \mathrm{nmol} / \mathrm{mg}$ of protein.

View the specific relationship between GSH and its metabolizing enzyme GST; no change in glutathiones-transferase activity was reported in the hepatopancreas of either controls or snails treated with copper oxide ( $p>0.05$; Figure 2-B; Table 1).

Unlike the first, the enzyme variation is significant in the kidneys $(\mathrm{p}<0.05$; Figure 2-B; Table 2$)$. In the control group, the enzymatic activity of GST was in the order of $2.76 \pm 0.49 \mathrm{nmol} / \mathrm{min} / \mathrm{mg}$ of protein but it was increased up to $4.04 \pm 0.72 \mathrm{nmol} / \mathrm{min} / \mathrm{mg}$ of protein in snails fed by $200 \mathrm{mg} / \mathrm{kg}$ of CuO-NPs. The only significant difference in the treated kidneys was noted between the two groups low $(50 \mathrm{mg} / \mathrm{kg})$ and high concentration $(200 \mathrm{mg} / \mathrm{kg})$ with a $\mathrm{p}<0.05$.

Gpx and catalase are the defense enzymes that are triggered when reactive oxygen species appear.

A very highly significant increase ( $p \leq 0.001$; Figure $2-C$, Table 1$)$ in the enzymatic activity of glutathione peroxidase was observed in the hepatopancreas following various treatments with copper oxide. Following the 45-day diet of healthy flour, the level of Gpx in the controls was $13.96 \pm 5.14 \mathrm{nmol}$ GSH / $\mathrm{mg}$ protein, while the flour mixed with the different concentrations of CuO-NPs induced a significant increase in Gpx up to $31.86 \pm 6.64 \mathrm{nmol} \mathrm{GSH} / \mathrm{mg}$ of protein in the case of $100 \mathrm{mg} / \mathrm{kg}$ of CuO-NPs.

A slight insignificant variation ( $p>0.05$; Figure 2-C, Table 2) in the defense enzyme was observed in the kidneys. The level of Gpx in controls was $17.37 \pm 4.76 \mathrm{nmol} \mathrm{GSH} / \mathrm{mg}$ protein, while in snails fed with the four concentrations of CuO-NPs the Gpx values ranged from 17 to $24 \mathrm{nmol}$ GSH / mg protein.

A positive correlation $(p<0.05)$ was established between the levels of GPx and catalase in the hepatopancreas, following the strong relationship between both enzymes in the elimination of ROS, which caused a very highly significant increase $(p=0.000$; Figure $3-A$, Table 1$)$ of catalase level in this organ. This variation is significant compared to the control group $(07.71 \pm 1.03 \mu \mathrm{mol} / \mathrm{min} / \mathrm{mg}$ of protein), and the highest value of which was reported in snails fed on flour mixed with $200 \mathrm{mg} / \mathrm{kg}$ of CuONPs $(18.34 \pm 2.15 \mu \mathrm{mol} / \mathrm{min} / \mathrm{mg}$ protein $)$ 
Since there was no significant variation in Gpx in the kidney, no change in catalase enzymatic activity was noted in this organ ( $p>0.05$; Figure $3-A$, Table 2 ).

One of the signs of the appearance of ROS in the cell is an increase in the lipid peroxidation index (LPO). After 45 days of exposure of 25 snails to 04 doses of copper oxide, a significant induction of LPO levels was observed in both studied organs; hepatopancreas $(p<0.05$; Figure 2-B, Table 1$)$ and kidney $(p=$ 0.000; Figure 3-B, Table 2).

In hepatopancreas, the level of LPO in controls was $0.645 \pm 0.176 \mathrm{nmol} / \mathrm{mg}$ protein and increased to $1.033 \pm 0.016 \mathrm{nmol} / \mathrm{mg}$ protein in individuals treated with $150 \mathrm{mg} / \mathrm{kg}$ of the oxide copper.

In the kidneys; peak LPO ( $\mathrm{p}<0.01)$ was present following exposure to 150 and $200 \mathrm{mg} / \mathrm{kg}$ CuO-NPs respectively; $2.314 \pm 0.09 \mathrm{nmol} / \mathrm{mg}$ of protein and $2.315 \pm 0.998 \mathrm{nmol} / \mathrm{mg}$ of protein compared to the control group $0.609 \pm 0.3 \mathrm{nmol} / \mathrm{mg}$ of protein.

\section{Discussion}

Copper is an essential element used in metabolic processes for both humans and animals (Bhattacharya et al. 2016). It is needed for crosslinking connective tissue as well as in iron and lipid metabolism (Siddiqui et al. 2013). However, excessive copper is extremely toxic and can cause various pathological changes in tissues (Ozcelik et al. 2003). Besides, CuO-NPs was shown to catalyze the formation of free radical species capable of triggering lipid peroxidation (Rikans and Hornbrook, 1997; Paresh et al. 2010).

While the respiratory tract is the most common route of nanoparticle exposure, the gastrointestinal tract is also a potential route of entry. Copper nanoparticles can be exposed to the gastrointestinal tract either through direct ingestion of water and food or through the mucociliary clearance of the respiratory tract which is subsequently ingested after swallowing (Chen et al. 2006).

The main objective of this study is to evaluate the induction of oxidative stress by copper oxide on the land snail Helix aspersa exposed to mixing of the nanoparticles and the wheat flour; for 45 days (subchronic exposure), with a battery of stress biomarkers (GSH, GST, GPx, CAT and LPO)

Glutathione (GSH) is the most important water-soluble and low-molecular antioxidant found in cells (Deneke and Fanburg, 1989). It has multiples physiological roles; as hydrogen peroxide scavenging and preservation of $\mathrm{SH}$ groups in a reduced state in proteins, enzymes, and some other molecules (Meister,1985). It plays a key role in cellular defense and serves as a reservoir for the amino acid cysteine.

In the present study, GSH contents in the hepatopancreas and kidney tissues of Helix aspersa exposed to CuO-NPs showed a significant decrease, except those exposed to 50,100 , and $200 \mathrm{mg} / \mathrm{kg}$ in the case of kidney tissues, when compared with the control groups after 45 days. These results are similar to Xiong et al. (2011); who studied the impact of ZnO on zebrafish, Abdel-Khalek et al. (2015) who exposed Oreochromis niloticus to a series of CuO-NPs concentrations, and Anreddy (2018), who treated the Wistar rat by CuO-NPs, all teams constated that NPs suspension caused a decrease in GSH content in the 
hepatopancreas tissue. Redox-active metal ions such as $\mathrm{Cu}$ (II) readily catalyze the oxidation of GSH giving rise to thiol and hydroxyl radicals (Stohs and Bagchi, 1995). This depletion can be a result of increased binding of $\mathrm{Cu}$ (stabilization of $\mathrm{Cu}$ in the oxidative state), enhanced use of GSH's oxidizing ability (conversion into GSSG, the oxidized form of glutathione), or an ineffective GSH regeneration (Pandey et al. 2001; Parvez et al. 2003; Ahmad et al. 2005; Parvez and Raisuddin, 2006). This depletion of GSH level reduces the cellular availability to scavenge free radicals and can lead to more oxidative stressrelated damage (Elia et al. 2003).

GST is an enzyme that catalyzes in the cytosol the conjugation reaction of electrophilic xenobiotics and their metabolites with an endogenous polar ligand which is glutathione (Habig et al. 1974). It is a key detoxifying enzyme that also plays an important role in eliminating ROS and scavenging lipid peroxidation metabolite (Wang et al. 2016).

The reduction of GST activity is could be explained by the deficiency and absence of biotransformation of xenobiotics and androgenic substances. Therefore, the GST has an important role in the neutralization and detoxification of certain xenobiotics by increasing their water solubility and thus facilitating their elimination (Vander et al. 2003).

Induction of the GST activity has already been reported in the snail Helix aspersa, exposed to various pollutants (Belhaouchet et al. 2012; Radwan and Mohamed, 2013; Hamdeni et al. 2014; Larba and Soltani, 2014).

All living organisms have protective systems against the reactions of free radicals, including antioxidant and oxidative stress enzymes. The activity of these antioxidant enzymes depends on the concentration and duration of exposure to pollutants, and the susceptibility of the species studied (Ballesteros et al. 2009).

GPx has a crucial role in intracellular protection against toxic compounds such as $\mathrm{Cu}$ and $\mathrm{Zn}$ (Anderson, 1997; Anderson and Luo, 1998; Mosleh et al. 2005). GPx is responsible for enzymatic defense against hydrogen peroxide and is strictly linked with the concentration of $\mathrm{GSH}$, it catalyzes the reaction between glutathione and hydrogen peroxide, resulting in the formation of glutathione disulfide (GSSG) (Alkaladi et al. 2013). In the present result, the GPx activity in the hepatopancreas tissues of Helix aspersa treated by copper oxide showed a significant increase when compared with control after 45 days. Witch is confirmed by Fahmy and Cormier (2009) who reported that CuO-NPs NPs were better able to increase the activity of GPx.

Catalase is a catalytic enzyme in the disproportionation of hydrogen peroxide (a SOD product generator) into the water and molecular oxygen (Delattre et al. 2005; Mohora et al. 2007). This hemoprotein protects tissues from hydroxyl radicals which are very reactive (Sathishsekar and Subramanian, 2005). In the present investigation, while CAT activities showed a significant increase in the case of hepatopancreas tissues of $H$. aspersa exposed to 04 concentrations of copper oxide, it showed a nonsignificant increase in kidney tissues, when compared with matched controls. 
CAT activity in invertebrates depends on the mode of exposure, species, and even within the same organism. Regoli et al. (2006) reported that vehicles' pollutants induced an increase in CAT activity in the digestive gland of Helix aspersa, however, it doesn't change when the species exposed to electromagnetic fields (Regoli et al. 2005). Some authors proposed that seasonal variations can affect catalase activity (Ramos-Vasconcelos et al. 2005). In contrast, Chandran et al. (2005) showed that enzyme activity was inhibited in the presence of Cadmium and Zinc in the snail Achatina fulica, in both target organs "hepatopancreas and kidney".

Lipid peroxidation was the classic result of oxidative damage and its byproduct was often formed when free radicals attacked cellular membranes (Chen et al. 2010). In the present study, the excessive level of TBA, a stable metabolite of lipid peroxidation, would further confirm the generation of oxidative damage in hepatopancreas and kidneys. All the above data suggest that nano-CuO-NPs affects the oxidationantioxidation homeostasis of both organs via increasing ROS and reducing antioxidant enzymes.

During the interpretation of our results, we observed the presence of a slight variation in the level of stress and defense biomarkers in the kidneys compared to hepatopancreas. A large number of studies have shown that excessive Cu results in inhibition of the levels of antioxidant enzymes while promoting the levels of lipid peroxidation in kidneys (Wang, 2017; Kumar, 2016).

\section{Conclusion}

It appears that copper oxide (CuO-NPs-NPs) used in this study can promote oxidative stress thus activating the detoxification system with an induction in the activities of GST, GPx, CAT, and a decrease in the content of GSH. These modifications are probably linked to the accumulation of ROS caused by the presence of NPs. Finally, the present study demonstrates that copper oxide nanoparticles induced hepatotoxicity and nephrotoxicity with potential enzymatic and biochemical disturbance.

\section{Statements \& Declarations}

"The authors declare that no funds, grants, or other support were received during the preparation of this manuscript."

\section{Conflict of interests}

The authors declare that they have no known competing financial interests or personal relationships that could have appeared to influence the work reported in this paper.

\section{References}

1. Deneke, S.M., Fanburg, B.L (1989). Regulation of cellular glutathione. Am J Physiol Lung Cell Mol Physiol.;257 4: L163-L73. 
2. Abdel-Khalek, A.A., Kadry, M.a.M., Badran, S.R., Marie, M.-a.S (2015). Comparative toxicity of copper oxide bulk and nano particles in Nile Tilapia; Oreochromis niloticus: biochemical and oxidative stress. J. Basic Appl. Zool. 72, 43-57. http://dx.doi.org/10.1016/j.jobaz.2015.04.001.

3. Ahmad, I., Oliveira, M., Pacheco, M., Santos, M.A. (2005). Anguilla anguilla L. oxidative stress biomarkers responses to copper exposure with or without b-naphthoflavone pre-exposure. Chemosphere 61, 267-275. https://doi.org/10.1016/j.chemosphere.2005.01.069

4. Alkaladi, A., Mosleh, Y.Y., Afifi, M (2013). Biochemical and histological biomarkers of Zn pollution in Nile Tilapia, (Oreochromis niloticus). Arch. Des Sci. 66, 295-311.

5. Anderson, M.E (1997). Glutathione and glutathione delivery compounds. Adv. Pharmacol. 38, 65-78. DOI: 10.1016/s1054-3589(08)60979-5

6. Anderson, M.E., Luo, J.L (1998). Glutathione therapy: from prodrugs to genes. Semin. Liver Dis. 18, 415-424. DOI: 10.1055/s-2007-1007174

7. Anreddy, R.N.R (2018). Copper oxide nanoparticles induces oxidative stress and liver toxicity in rats following oral exposure. Toxicol. Program Tech. Rep. Ser. 31, 903-904. https://doi.org/10.1016/j.toxrep.2018.08.022

8. Aruoja V., Dubourguier H.C., Kasemets K., Kahru A (2009). Toxicity of nanoparticles of CuO, ZnO and TiO 2 to microalgae Pseudokirchneriella subcapitata. Sci Total Environ 407(4):14611468 .https://doi.org/10.1016/j.scitotenv.2008.10.053

9. Beers R.F. JR., Sizer L.W (1952). A spectrophotometric method for measuring the breakdown of hydrogen peroxide by catalase.Biol. Chem. 195:133-140.

10. Belhaouchet N., Djebar M.R., Meksem L., Grara N., Zeriri I., Berrebbah Hn (2012). Evaluation of the biomarkers of the oxidative stress induced by a biopesticide: The Spinosad on an alternate model: Helix aspersa. Journal of Applied Sciences Research, 8(8), p.4199- 4206.

11. Bhattacharya, P.T., Misra, S.R., Hussain, M (2016). Nutritional aspects of essential trace elements in oral health and disease: an extensive review. Scientifica (Cairo) 2016, 5464373. https://doi.org/10.1155/2016/5464373

12. Bradford, M.M (1976). "A Rapid and Sensitive Method for the Quantization of Microgram Quantities of Protein Utilizing the Principle of Protein-Dye Binding." Analytical Biochemistry 72:248-254 https://doi.org/10.1016/0003-2697(76)90527-3.

13. Chandran R., Sivakumar A., Mohandass S., Aruchami M (2005). Effect of cadmium and zinc on antioxidant enzyme activity in the gastropod, Achatina fulica. Comparative Biochemistry and Physiology, Part C 140, 422-426. https://doi.org/10.1016/j.cca.2005.04.007

14. Chandran, R., Sivakumar A. A., Mohandass, S. et al (2005). "Effect of cadmium and zinc on antioxidant enzyme activity in the gastropod, Achatina fulica". Comparative Biochemistry and Physiology Part C: Toxicolology and Pharmacology, Vol. 14, pp. 422-426. http://dx.doi. org/10.1016/j.cca.2005.04.007

15. Chen, Q., Niu, Y., Zhang, R., Guo, H., Gao, Y., Li, Y., Liu, R (2010). The toxic influence of paraquat on hippocampus of mice: involvement of oxidative stress. Neurotoxicology 31, 310-316. 
https://doi.org/10.1016/j.neuro.2010.02.006

16. Chen, Z., Meng, H., Xing, G., Chen, C., Zhao, Y., Jia, G., Wang, T., Yuan, H., Ye, C., Zhao, F., Chai, Z., Zhu, C., Fang, X., Ma, B., Wan, L (2006). Acute toxicological effects of copper nanoparticles in vivo. Toxicol. Lett. 163 (2), 109-120. https://doi.org/10.1016/j.toxlet.2005.10.003

17. Coeurdassier M., Godot- de Vaufleury A., \& Badot P.M (2000). Dose-Dependent growth inhibition and bioaccumulation of hexavalent chromium in land snail Helix aspersa. Environmental Toxicology and Chemistry, 19, 2571-2578. https://doi.org/10.1002/etc.5620191025

18. Delattre, J., Beaudeux, J.L., Bonnefont, R (2005). Radicaux libres et stress oxydant : aspects biologiques et pathologiques. Lavoisier édition TEC \& DOC éditions médicales internationales Paris ; 353-376.

19. Elia, A.C., Galarini, R., Taticchi, M.I., Dorr, A.J.M., Mantilacci, L (2003). Antioxidant responses and bioaccumulation in Ictalurus melas under mercury exposure. Ecotoxicol. Environ. Saf. 55, 162-167. https://doi.org/10.1016/S0147-6513(02)00123-9

20. Fahmy B., and S.A. Cormier (2009). "CuO-NPs Induce Oxidative Stress and Cytotoxicity in Airway Epithelial Cells." Toxicology In Vitro 23:1365 - 1371. https://doi.org/10.1016/j.tiv.2009.08.005

21. Fatima M., Ahmad I., Sayeed I., Athar M., Raisuddin S (2000). Pollutant-induced overactivation of phagocytes is concomitantly associated with peroxidative damage in fish tissues. Aquat. Toxicol. 49, 243-250. https://doi.org/10.1016/S0166-445X(99)00086-7

22. Flohé L., Günzler W.A (1984). Assay of glutathione peroxidase. Methods Enzymol 105: 115-121.

23. François, P., (2012). Toxicité des nanoparticules métalliques chez différents modèles biologiques. Thèse de doctorat. Université du Québec à Montréal.

24. Ghosh M., Jana A., Sinha S., Jothiramajayam, M., Nag A., Chakraborty A., Mukherjee A., Mukherjee A (2016). Effects of ZnO nanoparticles in plants: Cytotoxicity, genotoxicity, deregulation of antioxidant defenses, and cell-cycle arrest. Mutat. Res. Genet. Toxicol. Environ. Mutagen., 807, 25-32. https://doi.org/10.1016/j.mrgentox.2016.07.006

25. Habig W.H., Pabst M.J., Jakoby W.B (1974). Gluthation-S-transferases: the first enzymatic step in mercapturic acid formation. Journal of Biological Chemistry 249, 7130-7139.

26. Hamdani A., Soltani Mazouni.N., Soltani N (2014).Quantitative and qualitative analysis of protéins in gonads of Donax trunculus from the Annaba Bay: effects of site, season and sex. Advances in Environmental Biology, 8(13): 740-749.

27. Heinlaan M., Ivask A., Blinova I., Dubourguier H., Kahru A (2008) . Toxicity of nanosized and bulk ZnO, $\mathrm{CuO}$ and $\mathrm{TiO}_{2}$ to bacteria Vibrio fischeri and crustaceans Daphnia magna and Thamnocephalus platyurus. Chemosphere 71:1308-1316. doi:10.1016/j.chemosphere. 2007.11.047

28. Huang Y., Cambre M., Han-Jung L (2017). The Toxicity of Nanoparticles Depends on Multiple Molecular and Physicochemical Mechanisms. International Journal of Molecular Sciences, 18, 2702; doi:10.3390/ijms18122702 
29. Kasemets K., Ivask A., Dubourguier H.C., Kahru A (2009). Toxicity of nanoparticles of ZnO, CuO and TiO 2 to yeast Saccharomyces cerevisiae. Toxicol In Vitro 23:1116-

1122 .https://doi.org/10.1016/j.tiv.2009.05.015

30. Kumar, S., Trivedi, A., Verma, N., Panwar, A., Kumar, P (2016). Evaluation of the serum levels of nitric oxide among diabetic patients and its correlation with lipid profile as well as oxidative stress in North Indian setting. J. Clin. Diagn. Res. 10 (5), OC44-OC47. doi: 10.7860/JCDR/2016/15548.7868

31. Larba R., Soltani N (2014). Use of the land snail Helix aspersa for monitoring heavy metal soil contamination in Northeast Algeria.Environmental Monitoring and assessment, lead through polluted ecosystem. Journal of Applied Ecology 22. 267-275.DOI:10.1007/s10661-014-3753-2. ISSN: 15732959

32. Mohora, M., Greabu, M., Muscurel, C., DuŃă, C., Totan, A (2007). The sources and the targets of oxidative stress in the etiology of diabetic complications, Rom J Biophys; 17, 63-84.

33. Mosleh, Y., Paris-Palacios, S., Couderchet, M., Biagianti-Risbourg, S., Vernet, G (2005). Metallothioneins induction, antioxidative response, glycogen and growth changed in Tubifex tubifex (Oligochaete) exposed to the fungicide, fenhexamid. Environ. Pollut. 135, 73-82. https://doi.org/10.1016/j.envpol.2004.10.012

34. Nezamzadeh-Ejhieh, A., Amiri, M (2013). CuO supported Clinoptilolite towards solar photocatalytic degradation of p-aminophenol. Powder Technology 235, 279-288.

https://doi.org/10.1016/j.powtec.2012.10.017

35. Ozcelik, D., Ozaras, R., Gurel, Z., et al (2003). Copper-mediated oxidative stress in rat liver. 96 (1-3), 209-215.

36. Pandey, S., Ahmad, I., Parvez, S., Bin-Hafeez, B., Haque, R., Raisuddin, S ( 2001). Effect of endosulfan on antioxidants of freshwater fish Channa punctatus Bloch: 1. Protection against lipid peroxidation in liver by copper pre exposure. Arch. Environ. Contam. Toxicol. 41, 345-352. DOI: $10.1007 / \mathrm{s} 002440010258$

37. Paresh, P., Janice, L., Tebello, N., et al (2010). Melatonin protects against copper-mediated free radical damage. $32(4), 237-242$.

38. Parvez, S., Raisuddin, S (2006). Copper modulates non-enzymatic antioxidants in the freshwater fish Channa punctata (Bloch) exposed to deltamethrin. Chemosphere 62, 1324-1332. https://doi.org/10.1016/j.chemosphere.2005.07.025

39. Parvez, S., Sayeed, I., Pandey, S., Ahmad, A., Bin-Hafeez, B., Haque, R., Ahmad, I., Raisuddin, S (2003). Modulatory effect of copper on non-enzymatic antioxidants in freshwater fish Channa punctatus (Bloch.). Biol. Trace Elem. Res. 93, 237-248.

40. Radwan M.A., Mohamed M.S (2013). Imidacloprid induced alterations in enzyme activities and energy reserves of the land snail, Helix aspersa. Ecotoxicology and Environmental Safety, 95:91-97. https://doi.org/10.1016/j.ecoenv.2013.05.019

41. Ramos Vasconcelos G.R., Cardoso L.A., Hermes-Lima M (2005). Seasonal modulation of free radical metabolism in estivating land snails Helix aspersa. Comparative Biochemistry and Physiology, Part C 
140: 165-174. https://doi.org/10.1016/j.cca.2005.01.015

42. Regoli F., Gorbi S., Fattorini D., Tedesco S., Notti A., Machella N., Bocchetti R., Benedetti M., Piva F (2006). Use of the land snail Helix aspersa as sentinel organisme for monitoring ecotoxicologic effects of urban pollution: An integrated approach. Environmental Health Perspectives. 114. p.63-69. https://doi.org/10.1289/ehp.8397

43. Regoli F., Gorbi S., Machella N., Tedesco S., Benedetti M., Bocchetti R. et al (2005). Prooxidant effects of extremely low frequency electromagnetic fields (ELF-EM) in the land snail Helix aspersa. Free Radic Biol \& Med 39: 1620-1628. https://doi.org/10.1016/j.freeradbiomed.2005.08.004

44. Rikans, L.E., Hornbrook, K.R (1997). Lipid peroxidation, antioxidant protection and aging. Biochim. Biophys. Acta (BBA) - Mol. Basis Dis. 1362 (2-3), 116-127. https://doi.org/10.1016/S09254439(97)00067-7

45. Rossi $F$ (2006). Recherche in vitro sur la toxicologie des nanoparticules au Joint Research Center. University Italy.

46. Sathishsekar, D., Subramanian, S (2005). Beneficial effects of Momordica charantia seeds in the treatment of STZ-induced diabetes in experimental rats. Biol Pharm Bull.;28:978-983. https://doi.org/10.1248/bpb.28.978

47. Siddiqui, M., Alhadlaq, H., Ahmad, J., Al-Khedhairy, A., Musarrat, J., Ahamed, M (2013). Copper oxide nanoparticles induced mitochondria mediated apoptosis in human hepatocarcinoma cells. PLoS One 8 (8). https://doi.org/10.1371/journal.pone.0069534

48. Stohs, S.J., Bagchi D (1995). Oxidative mechanisms in the toxicity of metal ions. Free Radic. Biol. Med. 18 (2), 321-336. https://doi.org/10.1016/0891-5849(94)00159-H

49. Van der Oost R., Beyer J. and Vermuelen N.P.E (2003). Fish bioaccumulation and biomarkers in environmental risk assessment: a review. Environemental Toxicology and Pharmacology. 13:57-149 https://doi.org/10.1016/S1382-6689(02)00126-6

50. Wang, H.W., Zhao, W.P., Liu, J., Tan, P.P., Zhang, C., Zhou, B.H (2017). Fluoride-induced oxidative stress and apoptosis are involved in the reducing of oocytes development potential in mice. Chemosphere 186, 911-918. https://doi.org/10.1016/j.chemosphere.2017.08.068

51. Wang, Z., Yin, L., Zhao, J., Xing, B (2016). Trophic transfer and accumulation of $\mathrm{TiO}_{2}$ nanoparticles from clamworm (Perinereis aibuhitensis) to juvenile turbot (Scophthalmus maximus) along a marine benthic food chain. Water Res. 95, 250 - 259. https://doi.org/10.1016/j.watres.2016.03.027

52. Weckberker, G., Cory, G (1988). Ribonucléotide reductase activity Abd growth of glutathione depleted mouse leukemial 1210 cells in vitro. Cancer letters 40, 257-264. https://doi.org/10.1016/03043835(88)90084-5

53. Xiong, D., Fang, T., Yu, L., Sima, X., Zhu, W (2011). Effects of nano-scale TiO 2 , ZnO and their bulk counterparts on zebrafish: acute toxicity, oxidative stress and oxidative damage. Sci. Total Environ. 409, 1444-1452. https://doi.org/10.1016/j.scitotenv.2011.01.015

54. Zhao Y., Xie P., Zhang X (2009). Oxidative stress response after prolonged exposure of domestic rabbit to a lower dosage of extracted microcystins. Environmental Toxicology and Pharmacology 27 


\section{Tables}

Table 1 : Levels of antioxidant enzyme (GSH, GST, GPx, CAT and LPO) in Helix aspersa hepatopancreas exposed to 50, 100, 150 and $200 \mathrm{mg} / \mathrm{kg}$ of CuO NPs for 45 days.

\begin{tabular}{|c|c|c|c|c|c|}
\hline Hepatopancreas & Control & $50 \mathrm{mg} / \mathrm{kg}$ & $100 \mathrm{mg} / \mathrm{kg}$ & $150 \mathrm{mg} / \mathrm{kg}$ & $200 \mathrm{mg} / \mathrm{kg}$ \\
\hline GSH & $5,13 \pm 1,81$ & $3,03 \pm 0,99$ & $4,02 \pm 1,86$ & $3,50 \pm 0,23$ & $4,04 \pm 1,02$ \\
\hline \multicolumn{6}{|l|}{ Nmol/mg of prot. } \\
\hline GST & $3,72 \pm 1,15$ & $4,21 \pm 0,26$ & $3,76 \pm 1,04$ & $4,23 \pm 0,31$ & $4,27 \pm 0,33$ \\
\hline \multicolumn{6}{|l|}{$\begin{array}{l}\mathrm{Nmol} / \mathrm{min} / \mathrm{mg} \mathrm{de} \\
\text { prot. }\end{array}$} \\
\hline GPX & $13,96 \pm 5,14$ & $28,73 \pm 4,04$ & $31,86 \pm 6,64$ & $24,71 \pm 3,72$ & $25,07 \pm 6,05$ \\
\hline $\begin{array}{l}\mathrm{Nmol} \mathrm{GSH} / \mathrm{mg} \text { of } \\
\text { prot. }\end{array}$ & & * & * & & \\
\hline \multirow{2}{*}{$\begin{array}{l}\text { CAT } \\
\mu \mathrm{mol} / \mathrm{min} / \mathrm{mg} \text { of } \\
\text { prot. }\end{array}$} & $7,71 \pm 1,03$ & $13,38 \pm 1,99$ & $17,21 \pm 1,24$ & $17,63 \pm 3,48$ & $18,34 \pm 2,15$ \\
\hline & & ** & $\star \star \star$ & $\star \star \star *$ & $\star \star \star$ \\
\hline \multirow{2}{*}{$\begin{array}{l}\text { LPO } \\
\text { Nmol/mg of prot. }\end{array}$} & $\begin{array}{l}0,645 \pm \\
0,176\end{array}$ & $\begin{array}{l}0,799 \pm \\
0,121\end{array}$ & $\begin{array}{l}0,815 \pm \\
0,173\end{array}$ & $\begin{array}{l}1,033 \pm \\
0,016\end{array}$ & $\begin{array}{l}0,908 \pm \\
0,108\end{array}$ \\
\hline & & & & ** & * \\
\hline
\end{tabular}

Table 2 : Levels of antioxidant enzyme (GSH, GST, GPx, CAT and LPO) in Helix aspersa kidney exposed to $50,100,150$ and $200 \mathrm{mg} / \mathrm{kg}$ of CuO NPs for 45 days. 


\begin{tabular}{llllll} 
Kidney & Control & $50 \mathrm{mg} / \mathrm{kg}$ & $100 \mathrm{mg} / \mathrm{kg}$ & $150 \mathrm{mg} / \mathrm{kg}$ & $200 \mathrm{mg} / \mathrm{kg}$ \\
\hline GSH & $3,49 \pm 1,46$ & $3,78 \pm 1,40$ & $3,67 \pm 1,70$ & $1,90 \pm 0,03$ & $3,85 \pm 1,25$
\end{tabular}

$\mathrm{Nmol} / \mathrm{mg}$ of prot.

GST $\quad 2,76 \pm 0,49 \quad 2,17 \pm 0,41 \quad 3,42 \pm 0,79 \quad 3,50 \pm 1,28 \quad 4,04 \pm 0,72$

$\mathrm{Nmol} / \mathrm{min} / \mathrm{mg}$ de prot.

GPX

$17,37 \pm 4,76$

$18,10 \pm 3,04$

$20,06 \pm$
2,57

$16,98 \pm 2,96 \quad 23,57 \pm 3,97$

$\mathrm{Nmol} \mathrm{GSH} / \mathrm{mg}$ of prot.

\section{CAT}

$13,82 \pm 1,70$

$15,08 \pm 3,94$

$16,30 \pm$ 3,01

$16,31 \pm 2,17$

$17,08 \pm 3,78$

$\mu \mathrm{mol} / \mathrm{min} / \mathrm{mg}$ of prot.

LPO

$\mathrm{Nmol} / \mathrm{mg}$ of prot.

$0,609 \pm$

0,300
$0,541 \pm$

0,253
$0,859 \pm$

0,36
$2,314 \pm$

0,093
2,315

$\pm 0,998$

\section{Figures}




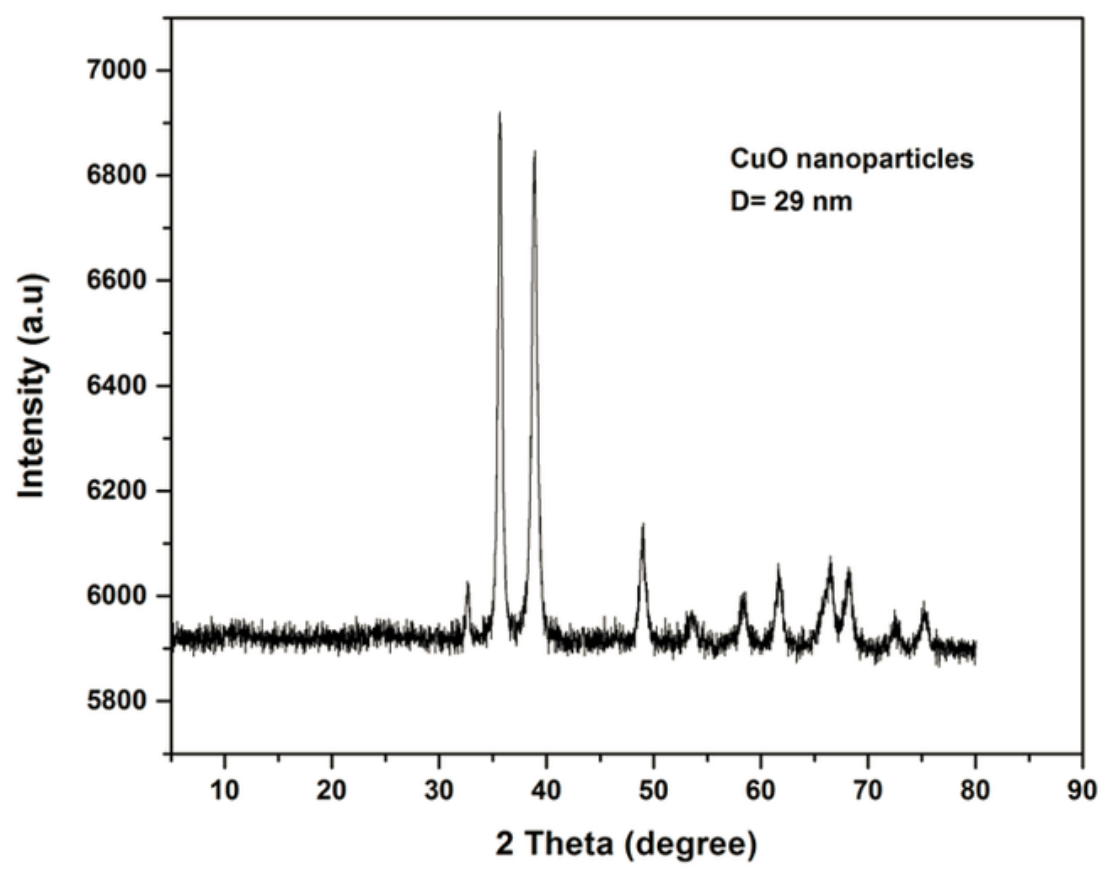

(a)

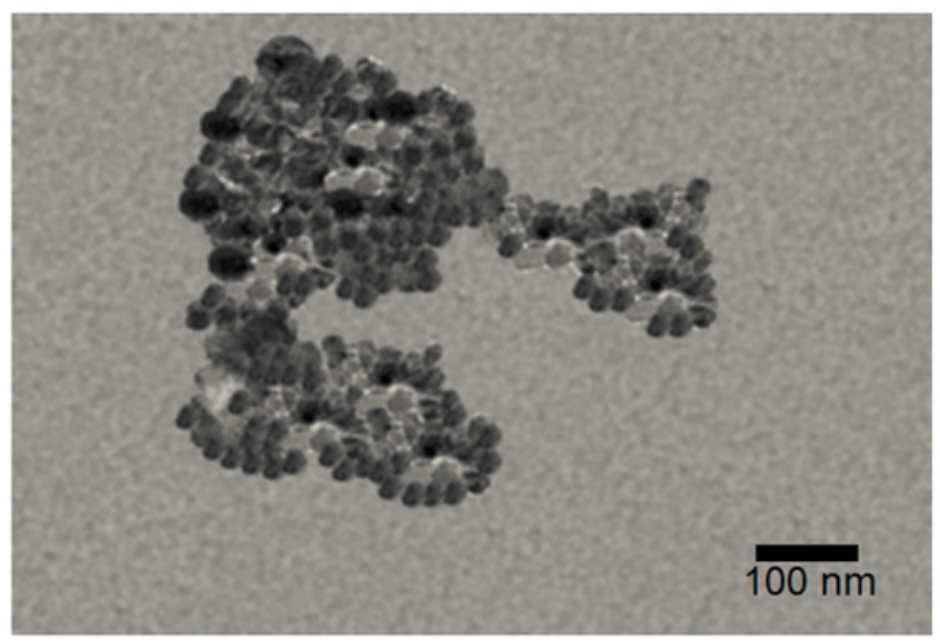

(b)

\section{Figure 1}

A. XRD pattern of $\mathrm{CuO}$ nanoparticles $\mathrm{B}$. TEM image of the $\mathrm{CuO}$ nanoparticles 

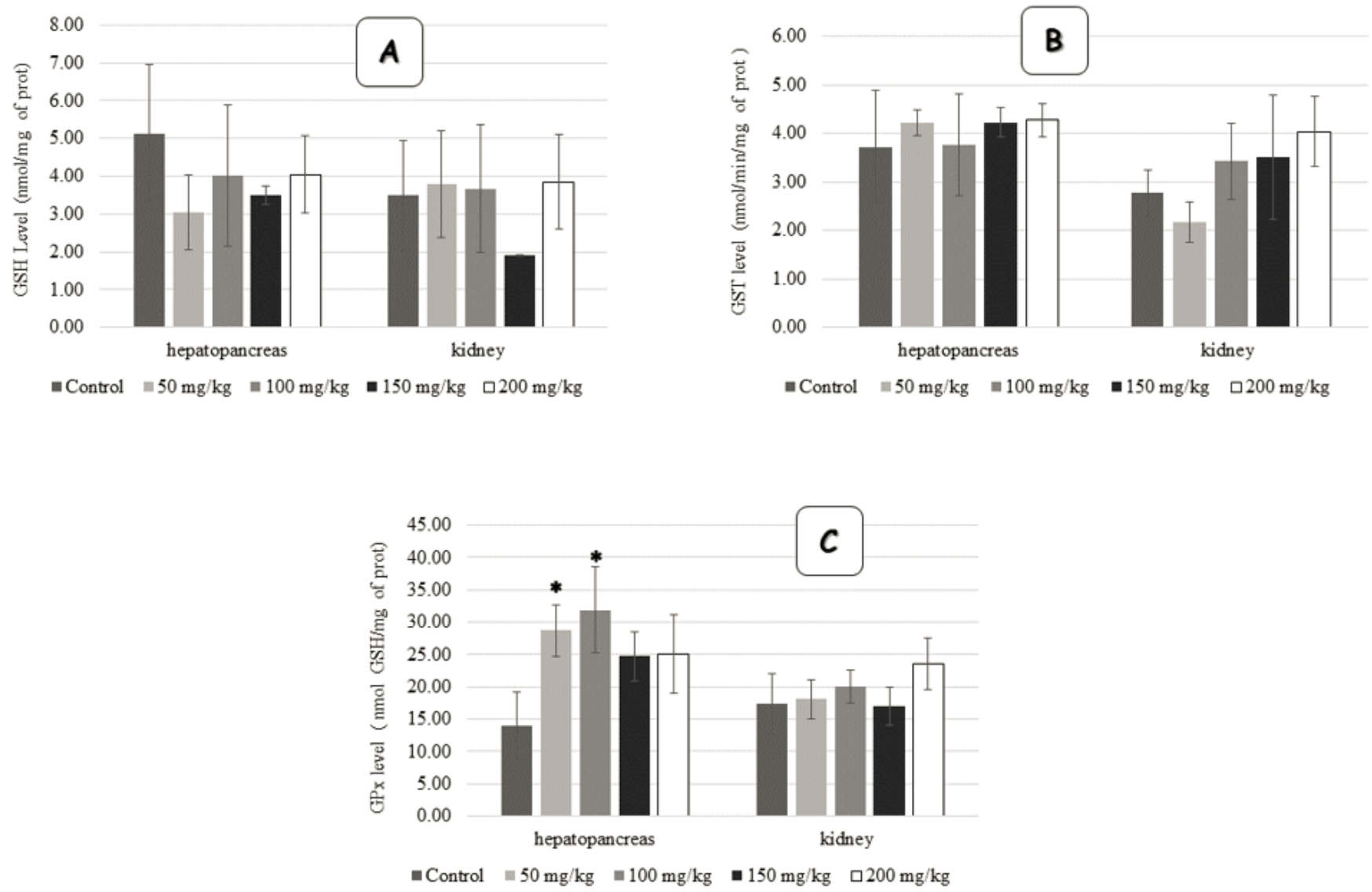

Figure 2

GSH (A), GST (B) and GPx (C) values Helix aspersa's organs exposed to CuO. The values are expressed as mean \pm S.E. The number of measurements performed in each group was three.
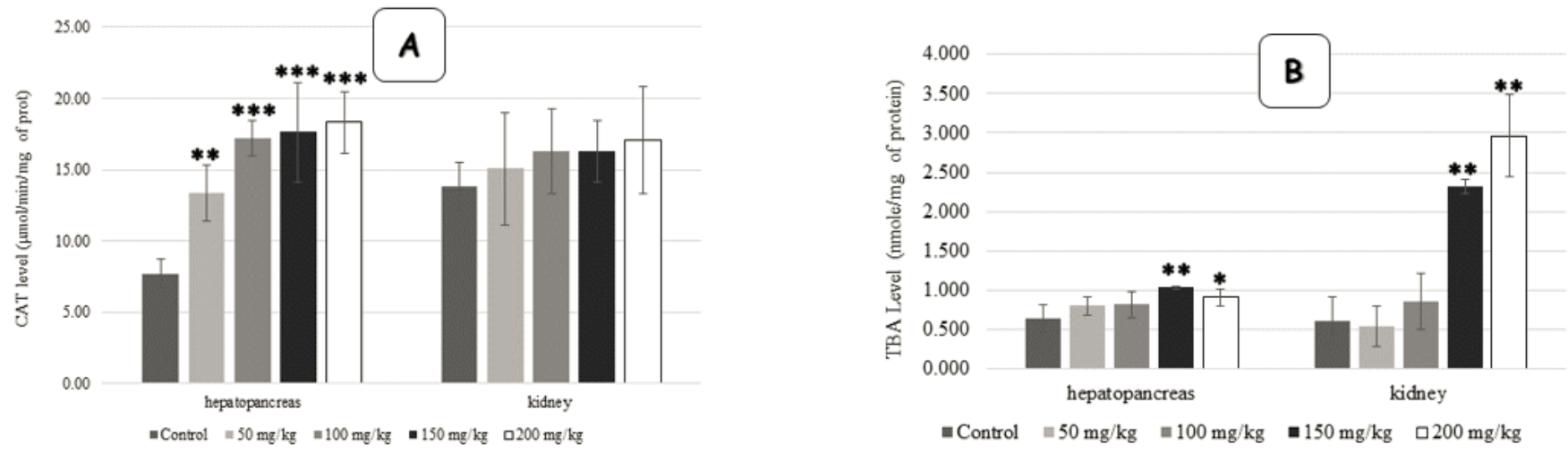

Figure 3 
CAT (A) and LPO (B) values in Helix aspersa's organs exposed to CuO. The values are expressed as mean \pm S.E. The number of measurements performed in each group was three.

\section{Supplementary Files}

This is a list of supplementary files associated with this preprint. Click to download.

- graphicabstract.png 